\title{
DETERMINANT FACTORS OF UNDERNUTRITION IN PETOAHA VILLAGE: PATH ANALYSIS
}

\author{
Fitri Rachmillah Fadmi ${ }^{1}$, La Djabo Buton ${ }^{2}$ \\ ${ }^{1,2}$ Departement Of Publich Health Stikes Mandala Waluya Kendari, Southeast Sulawesi \\ Province, Indonesia
}

Corresponding Author: Fitri Rachmillah Fadmi

Email : Fitri.rachmillahfadmi@gmail.com

\section{Abstract}

Background: Nutrition is still a public health problem in Indonesia. Good nutritional intake cannot be provided by children, because of the mother's knowledge, family income, and nutritional intake. Analysis of the factors that influence nutrition in children under five in Petoaha Village.

Methods:This type of research is an analytic observational with cross-sectional study design. The population and sample in this study were under nutrition data in Petoaha Village.

Results: The results of the path analysis show that the model fits the data with a value of RMSEA $=0.000<0.10$. Furthermore, based on the pathway with the estimation model and the $t$ calculation shows that four factors are interrelated based on the $t_{\text {calculation }}>1.96$, namely between income and under nutrition getting $\mathrm{t}_{\text {calculation }} \mathrm{n}=3.25$; knowledge by under nutrition obtained $\mathrm{t}_{\text {calculation }}=5.06$; knowledge of nutritional intake was obtained by $\mathrm{t}_{\text {calculation }}=2.10$ and malnutrition intake, $\mathrm{t}_{\text {calculation }}=2.16$.

Conclusion: It is hoped that it can become an information reference for policymakers in implementing preventive and promotive efforts from an early age to the community in overcoming under nutrition.

Keywords : under nutrition, path, analysis 


\section{INTRODUCTION}

Nutrition is a determinant of the quality of human resources. Foods that are given daily must contain nutrients as needed, to support optimal growth and can prevent a deficiency disease, poisoning, and the emergence of diseases that can interfere with children's survival(1). Nutrition problems are health problems of a person or community caused by the imbalance in fulfilling their needs for nutrients obtained by food. Undernutrition that occurs in the first two years of life is permanent, it cannot be recovered even though the nutritional needs in the next period have been met. One of the most worrying nutritional problems that occur in society is the problem of malnutrition(2). The Global Situation based on World Health Organization (WHO) data in 2017 shows that the number of child deaths under the age of 5 reaches 5.9 million worldwide(3). India in 2011 which accounted for $38 \%$ of the global stunting burden (nearly 62 million children) underlines the difficulty of reducing malnutrition in India. Meanwhile, UNICEF reports that as many as 167 million preschool children in the world who are underweight are mostly in South Asia. (4).

Another point suggests that per capita fixed income (or economic growth) employed in India between 1992 and 2006 was not approved in Nutritional Wealth Reduction(5). In parallel, support the momentum to make direct investments in programs and interventions aimed at nutrition (for example, contributing, providing supplementary food, micronutrition, and providing therapeutic and supplementary foods), health (for example, discussing and managing infectious diseases) and water, sanitation, and cleanliness programs (WASH) $(6,7)$.

Basic health research data shows that in Indonesia the prevalence of malnourished children under five is $4.9 \%$ and undernutrition is $13 \%$ or nationally the prevalence of under-five children with undernutrition and under-nutrition is $17.9 \%$, both indicate that both the medium-term development plan targets for program achievement improvement of nutrition by $20 \%$ and the target of the Millennium Development Goals in $201518.5 \%$ have been achieved. But there are still disparities between provinces that need to be dealt with problems that are specific in vulnerable areas. According to the Head of Health research department of the Ministry of Health, Trihono said that from 2013 The basic health research data the tendency in each province in 2013 to be underweight was $19.6 \%$, up from $18.4 \%$. While the region with the highest number of malnourished children under five is NTT around 34\%(8).

Undernutrition problems also occur in Southeast Sulawesi Province. Data from the Southeast Sulawesi Provincial Health Office shows that cases of undernutrition in 2014 reached 250 cases, although this number decreased compared to 2013, which was 333 cases. Whereas in 2015 undernutrition cases still reached 245 cases. Cases of undernutrition are found in all districts and cities in Southeast Sulawesi Province(9). Data from the KendariCity Health Office shows that in 2016 the number of undernutrition cases reached 75 cases, then decreased in 2017 with 48 cases and in 2018 with 45 cases. However, the problem of undernutrition in Kendari City remains a very concerning health problem even though in the last 3 years there has been a significant decrease because it is still the first in the number of undernutrition cases in Kendari City, with the highest case being the working area of the Nambo Community Health Center. The increase in cases in 3 years occurred from 2016 to 2018 in the work area of the Nambo Community Health Centre with the highest number of cases in Petoaha Village(10).

Based on the above case the researchers tried to examine how to find out the lack of nutrition by looking at the mother's knowledge, family income level, mother's parenting. In this study, a statistical analysis will be examined that can detect the 
magnitude of the influence of these factors on the incidence of undernutrition. One statistical analysis that can be used to analyze the cause and effect relationships of several variables is path analysis.

Path analysis is the development of a regression model used to test the suitability of the correlation matrix against two or more causal models compared by researchers which are usually depicted in the form of a single-headed circle and arrow indicating the cause. Regression is carried out on each variable in the model as a relationship to one another indicated by the model as a cause. The regression weights predicted by the model are compared with the observed correlation matrix for the variables, and the goodness of fit statistic is calculated. The most suitable model of two or more models is selected by the researcher as the best model for theoretical progress. (11). The analysis is used to describe and test the model of the relationship between variables in the form of cause and effect (correlation and causality). Correlation means the statistical relationship between a set of variables that causes a conclusion. The relationship is described in the form of a path diagram to facilitate the formulation of theory into the form of a path model. Model specifications are needed in examining the relationships of several variables in the path model, as in the case of homepage regression(12). This study aims to determine the path analysis of the incidence of undernutrition infants in Petoaha Village, Nambo District, Kendari City.

\section{METHOD}

This type of research is analytic observational with a cross-sectional design, namely research that measures the independent variable and the dependent variable on the object of research at the same time. The population in this study were all data on under-five nutrition in Petoaha Village, Nambo District, Kendari City.

The research variables in this study consisted of the dependent variable and the independent variable. The dependent variable is malnutrition. While the independent variables include the mother's knowledge, family income level, parenting style, history of exclusive breastfeeding, health service utilization. Data analysis was carried out by path analysis in analyzing the relationship pattern between variables which aims to determine the effect, either directly or indirectly, of a group of independent variables on a dependent variable.(13)

\section{RESULT}

Descriptive analysis results show that the majority of respondents aged 31-35 years with a total of 13 respondents (21\%), educated junior and senior high school with a total of 23 respondents each (37.1\%), have toddlers with nutritional status of 39 respondents $(62.9 \%)$, nutritional intake of under-fives with underweight by 25 respondents $(40.3 \%)$, low family income with 28 respondents $(45.2 \%)$, low maternal knowledge with $30(48.4 \%)$ respondents and the majority of parenting mothers are also low $27(43.5 \%)$ respondents.

The results of the path analysis in figures 1 and 2 show that the $\mathrm{X} 2$ value is used to test how close the result of the alleged matrix to the original data matrix. The smaller the measurement value, the better the model used. X2calculation obtained is 0.77 with $\mathrm{p}$-value $=0.37887>\mathrm{a}$, then the model is fitted with the data. This means that the input matrix with the estimated matrix does not differ so that the model is fitted with the data. Furthermore, from the output obtained RMSEA value = 0,000. RMSEA values are statistical measures that must be met in a model match test. RMSEA value is said to be good if the value is smaller than 0.05 , reasonable if it is smaller than 0.08. thus it was concluded that based on the RMSEA value obtained, the model was said to be fit. The magnitude of the influence of the indicators from the largest to the smallest in a row can be seen in Table 1. 
Fadmi, F. R., \& Buton, L. D.

DOI: $10.36566 /$ ijhsrd/Vol2.Iss1/25

https://ijhsrd.com/index.php/ijhsrd

e- ISSN: 2715-4718

Table 1. Contributions of indicators

\begin{tabular}{clcc}
\hline Dependent Variable & \multicolumn{1}{c}{ IndependentVariable } & Contribution & $\mathbf{t}_{\text {calculation }}$ \\
\hline \multirow{3}{*}{ Under nutrition } & Mother's Knowledge & 0,49 & 3,25 \\
\cline { 2 - 4 } & Family Income & 0,30 & 5,06 \\
\cline { 2 - 4 } & Nutrition intake & 0,20 & 2,16 \\
\hline \multirow{2}{*}{ Nutrition intake } & Mother's Knowledge & 0,28 & 2,10 \\
\cline { 2 - 4 } & Family Income & 0,01 & 0.07 \\
\hline
\end{tabular}

\section{DISCUSSION}

Under nutrition analysis is based on maternal knowledge, income, nutritional intake, and parenting. In addition, different characteristics such as geographical distribution that indicate nutritional problems between regions will cause different health qualities in each region(14).The results obtained significant correlations obtained between maternal knowledge, income, nutritional intake, and parenting with the incidence of under nutrition. Significant correlation is the correlation between direct and indirect effects through path analysis(15).

The knowledge path to under nutrition obtained a $t_{\text {calculation }}=5.06>1.96$, with an effect of $49 \%$.This shows that sufficient knowledge has a positive influence on under nutrition. Mother's knowledge and education are someof the factors that can determine the nutritional status of a family, because education can help to get information about nutritional health.Thus on the knowledge pathway to nutritional intake, the value of $\mathrm{t}_{\text {calculation }}=2.10>1.96$ was obtained, with an effect of $28 \%$. This shows that knowing has enough positive influence on nutrient intake.This relates to the theory which says that a person's level of nutritional knowledge influences attitudes and behaviors in choosing food that determines whether or not someone easily understands the benefits of the nutritional content of the food consumed ${ }^{(16)}$.A mother's educationis the risk factor to under nutrition. This is because educated mothers will better know and understand the health and nutritional conditions of their children. Thus the child will get better care, have better hygienic practices and also have a higher status in the family. In addition, it is known that better economic conditions will improve the standard of living for families, allowing them to care for children(17).The mothers' knowledge and competence as care provider have a key role in the nutritional outcome and growth of children.Lack of mothers' knowledge may be the reason of poor feeding practices. Assistance and guidance of mothers can benefit them in the better utilization of available resources for the health of their children(18). It is assumed thatthe mothers who have true nutritional knowledge prefer right foods for themselves and for their children(19).In addition, the knowledge and awareness of mothers in breastfeeding is very closely related to the nutritional condition of infants(20). The findings from this study can improve our understanding of the role of mothers who have good knowledge about nutrition against under nutrition. Mother's knowledge in choosing types of food, feeding and health care is very important in producing good nutrition for her children(21).

The family income channel for under nutrition obtained tcalculation $=3.25>1.96$ with a influence of $30 \%$, this indicates that sufficient income has a positive influence on under nutrition. The same research results finds that household income affected child nutritional status significantly through the mechanisms of community, household, parental and individual factors(22).Low income has always been a background to health and nutrition issues. The results showed that found a relationship between socio economic status and nutritional 
status(23). Most of the family income factors are related to socioeconomic status, although the father's income is not earned, the mother's income and household monthly food expenses are significant risk factors. In addition, children whose mothers have less than secondary education are at a higher risk of malnutrition than those whose mothers have an education beyond primary school level.(24). Low income will affect many things such as food consumption patterns become less nutritious, so with health care, the cost of illness cannot afford, and if sick do not immediately seek treatment. One of the causes of low family income is the level of education that is too low. The level of education, especially mother's education can affect the quality of childcare, while also affecting the degree of health because the element of maternal education is very influential on changes in attitudes and healthy living behavior. A higher level of education will make it easier for people to absorb information and implement it in their daily behavior and style. Poverty is also a condition that is described as a lack of income to meet the most basic necessities of life such as food, clothing, shelter and others. One result of the lack of job opportunities is the low income of the people(25).Areas with high population density tend to haveslums, hygiene, bad nutrition causes many families with low incomes.An increase in families with low incomes will causefulfilment of nutrition becomes difficult to reach soimpact on under nutrition(26).

Pathway of nutrient intake to Underweight Nutrition obtained $\mathrm{t}_{\text {calculation }}=$ 2.16> 1.96, this shows that income has a positive influence on under nutrition. According to Sobotka and Forbes(2019), nutritional status is released directly by the level of energy consumption obtained from carbohydrates, proteins, and fats. Energy needed for growth, interaction, food use and activities. It takes energy created by fats and fats, while proteins need to provide amino acids for the synthesis of cell proteins and hormones and enzymes to measure metabolism. Food needed by humans to support growth, maintain life, and carry out physical activity. If food consumption is less than the body's needs, then the food reserves needed in the body that are stored in muscles and fat will be used. This lack of intake takes time in a long period of time it will be reduced in the body and lack of other substances(27).Continued weight loss will cause under nutrition which will result in stunted growth and development processes. Other impacts that can arise a person easily infected with infectious diseases and decreased academic achievement. While excessive food consumption can lead to weight gain and if it continues it will cause obesity and the risk of degenerative diseases. This good nutritional status is inseparable from the value of adequate nutrition (energy). A healthy child in a good nutritional state because enough quality food experiences body growth with body weight according to age is called healthy weight. In other words, a good nutritional status can be seen from the good AKE value(28).

\section{CONCLUSION}

The conclusion of this study is the knowledge pathway to under nutrition has an effect of $49 \%$. This shows that sufficient knowledge has a positive influence on under nutrition. Mother's knowledge and education is one of the factors that can determine the nutritional status of a family, because education can help with information about nutrition. family income to under nutrition has an effect of $30 \%$. Family income can guarantee a baby's nutritional status will be better, if the income is large enough to meet the nutritional needs of the family. The nutritional intake pathway for under nutrition has an effect of $20 \%$. A healthy child in a good nutritional state because enough quality food experiences body growth with body weight according to age is called healthy weight.

\section{Indonesian Journal Of Health Sciences Research and Development




\section{REFERENCES}

1. Soekirman. Taking the Indonesian nutrition history to leap into betterment of the future generation: development of the Indonesian Nutrition Guidelines. Asia Pacific Journal of Clinical Nutrition. 2011;20(3):447-51.

2. Merryana Adriani S, Kes M. Pengantar gizi masyarakat: Prenada Media; 2016.

3. Unicef. WHO, World Bank Group (2017) Levels and trends in child malnutrition. USA: UNICEF, WHO \& World Bank Group. 2017.

4. Gupta P, Zhao D, Guallar E, Ko F, Boland MV, Friedman DS. Prevalence of glaucoma in the United States: the 2005-2008 national health and nutrition examination survey. Investigative ophthalmology \& visual science. 2016;57(6):2905-13.

5. Corsi DJ, Subramanyam MA, Subramanian S. Commentary: Measuring nutritional status of children. International journal of epidemiology. 2011;40(4):1030-6.

6. Koletzko B, Bhatia J, Bhutta ZA, Cooper P, Makrides M, Uauy R, et al. Pediatric nutrition in practice: Karger Medical and Scientific Publishers; 2015.

7. Black RE, Alderman H, Bhutta ZA, Gillespie S, Haddad L, Horton S, et al. Maternal and child nutrition: building momentum for impact. The Lancet. 2013;382(9890):372-5.

8. Penelitian B. Riset kesehatan dasar (Riskesdas) 2013. Lap Nas. 2013;2013(1):384.

9. Tenggara DKPS. Profil Kesehatan Provinsi Sulawesi Tenggara Tahun 2018. Kendari: Dinas Kesehatan Provinsi Sulawesi Tenggara. 2019.

10. Kendari DKK. Profil Dinas Kesehatan Kota Kendari. 2018.

11. Garson GD. Path analysis: Statistical Associates Publishing Asheboro, NC; 2013.

12. Sarwono J. Analisis Jalur (Path Analysis). Jakarta: Gramedia. 2011.
13. Riadi E. Aplikasi LISREL untuk penelitian analisis jalur. Yogyakarta: CV Andi Offset. 2013.

14. Fadmi FR, Mulyani S, Buton LD. Geographically Weighted Regression (GWR) Approach in the Modeling of Malnutrition and the Influencing Factors in Muna Regency. Indian Journal of Public Health Research \& Development. 2018;9(6).

15. Rodrigues WN, Colodetti TV, Martins LD, Brinate SVB, Tomaz MA, do Amaral JFT. Nutritional components of growth of Arabica coffee genotypes cultivated under different levels of phosphorus fertilization studied by path analysis. Australian Journal of Crop Science. 2015;9(12):1214.

16. Mulyati T, Ginting FR, Bahagiawati H, Aizahroni A. Hubungan antara Pengetahuan tentang Anemia dengan Asupan Gizi pada Ibu Hamil dengan Resiko Terjadinya Anemia dalam Kehamilan di Puskesmas Kecamatan Kembangan, Jakarta Barat Periode 1018 Desember 2007. Ebers Papyrus. 2018;13(4):169-76.

17. Ahmed T, Roy S, Alam N, Hossain MI. Determinants of undernutrition in children under 2 years of age from rural Bangladesh. Indian pediatrics. 2012;49(10):821-4.

18. Kaleem R, Adnan M, Naveed $\mathrm{S}$. Association of mothers' sociodemographic characteristics with their knowledge and practices about complementary feeding. Journal of Fatima Jinnah Medical University. 2018;12(2).

19. Yabancı N, Kısaç İ, Karakuş SŞ. The effects of mother's nutritional knowledge on attitudes and behaviors of children about nutrition. ProcediaSocial and Behavioral Sciences. 2014;116:4477-81.

20. Syeda B, Agho K, Wilson L, Maheshwari GK, Raza MQ. Relationship between breastfeeding duration and undernutrition conditions 
Fadmi, F. R., \& Buton, L. D.

DOI: 10.36566/ijhsrd/Vol2.Iss1/25

https://ijhsrd.com/index.php/ijhsrd

among children aged 0-3 Years in Pakistan. International Journal of Pediatrics and Adolescent Medicine. 2020.

21. Fadare O, Amare M, Mavrotas G, Akerele D, Ogunniyi A. Mother's nutrition-related knowledge and child nutrition outcomes: Empirical evidence from Nigeria. PloS one. 2019;14(2).

22. Wu Y. What is known about children's undernutrition and health levels in China-An empirical analysis from 1991 to 2009. Children and Youth Services Review. 2019;96:372-80.

23. Bhandari S, Ghosh M, Bose K. SocioDemographic Characteristics and Prevalence of Under Nutrition among Adult Sabars of Bankura District, West Bengal, India. International Journal of Advancement in Life Sciences Research. 2019:1-10.

24. Owoaje E, Onifade O, Desmennu A. Family and socioeconomic risk factors for undernutrition among children aged 6 to 23 Months in Ibadan, Nigeria. The Pan African medical journal. 2014;17.

25. Saputra W, Nurrizka RH. Faktor demografi dan risiko gizi buruk dan gizi kurang. Makara kesehatan. 2012;16(2):95-101.

26. Fadmi FR, Mulyani S. ANALISIS FORECASTING PADA JUMLAH KASUS GIZI BURUK DI PROVINSI SULAWESI TENGGARA TAHUN 2019-2023. Preventif Journal. 2019;4(1).

27. Sobotka L, Forbes A. Basics in clinical nutrition: Galen; 2019.

28. Ayogu RN, Afiaenyi IC, Madukwe EU, Udenta EA. Prevalence and predictors of under-nutrition among school children in a rural South-eastern Nigerian community: a cross sectional study. BMC public health. 2018;18(1):587. 